\title{
片脚着地時の体幹肢位が膝関節角度と 筋活動に及ぼす影響
}

\author{
——男女間の比較—— \\ Influence of Trunk Posture on Knee Joint Angle and Muscle Activity during Single-leg \\ Landing: A Comparison by Gender
}

\begin{abstract}
齊藤 明 1) 佐々木 誠 ${ }^{1)}$ 若狭 正彦 ${ }^{1)}$ 上村 佐知子 1) 岡田 恭司 ${ }^{1)}$
AKIRA SAITO $^{1)}$, MAKoto SASAKI ${ }^{1)}$, MASAhIKo WAKASA ${ }^{1)}$, SACHIKo UEMURA $^{1)}$, KYOJI OKADA $^{1)}$

1) Department of Physical Therapy, Akita University Graduate School of Health Sciences: 1-1-1 Hondo, Akita-shi, Akita 010-8543, Japan.TEL+81 18-884-6552E-mail:ptsaito@hs.akita-u.ac.jp
\end{abstract}

Rigakuryoho Kagaku 29(6): 955-959, 2014. Submitted Jun. 19, 2014. Accepted Aug. 2, 2014.

\begin{abstract}
Purpose] The purpose of this study was to clarify the influence of trunk posture and gender on the knee joint angle and muscle activity during single-leg landing. [Subjects and Methods] Forty healthy college students were enrolled in the present study. The participants performed single-leg landing from a $40 \mathrm{~cm}$-high platform using one of the three trunk postures: preferred, flexion, and right lateral flexion. The knee flexion and valgus angle was measured, and the hamstrings/quadriceps ratio (HQR) was calculated for each trunk posture. [Results] The knee flexion angle was significantly greater in the flexed posture, whereas the knee valgus angle was significantly greater in the right lateral flexed posture. In addition, the knee valgus angle was significantly higher in females, and the HQR was significantly lower in females than in males. [Conclusion] Both the trunk posture and gender affected the knee angle and muscle activity during single-leg landing. These findings are likely related to the differences in the incidence of anterior cruciate ligament injury between males and females.
\end{abstract}

Key words: landing, trunk posture, gender

要旨：〔目的〕体幹肢位および性別が片脚着地時の膝関節角度や筋活動に及ぼす影響を明らかにすることである。〔対 象〕健常大学生 40 名とした。〔方法〕自然で楽な姿勢, 体幹屈曲位, 右側屈位での高さ $40 \mathrm{~cm} の$ 台からの片脚着地 動作を行い，この時の膝関節屈曲と外反角度，および hamstrings / quadriceps ratio（HQR）を，これらの体幹肢位間 および男女間で比較した。〔結果〕他の肢位に比べ体幹屈曲位では膝関節屈曲角度, HQR が有意に高く, 体幹右側屈 位では膝関節外反角度が有意に大きかった。女性では男性に比べ膝関節外反角度が有意に高く, HQRが有意に低かっ た.〔結語〕体幹肢位, 性別は片脚着地時の膝関節角度と筋活動に影響を及ぼし, 前十字䩲帯損傷の一要因であるこ とが示唆される.

キーワード : 着地動作, 体幹肢位, 性別

1) 秋田大学大学院 医学系研究科 保健学専攻 理学療法学講座:秋田県秋田市本道 1-1-1 ( T 010-8543) TEL 018-884-6552 


\section{I.はじめに}

前十字勒带（anterior cruciate ligament：ACL）損傷は， スポーツ活動中に発生することが多く, 約 7 割が非接触 型損傷 1 である。その中でもジャンプの着地が最も多 い受傷動作の 1 つ2)であることから, 着地時の下肢ア ライメントが ACL 損傷の危険因子として重要視されて きた 3,4$)$. 近年ではこの因子に加え，体幹肢位も重要視 されている5)がその報告数は少ない. ACL 損傷時の映 像解析では, ACL 損傷群が非損傷群に比べ体幹側屈角 度が大きく，この角度の増大が ACL 損傷の危険因子で ある ${ }^{6)}$ と報告されているが, 体幹側屈が膝関節角度に どのような影響を及ぼすかは明らかにされていない．ま た女性では男性に比べ受傷者数が $2 \sim 8$ 倍多く 2,7 , 非接 触型損傷の割合も 3 倍7)であるとされている。 その理 由として内的要因や外的要因などが報告 ${ }^{8)}$ されている が，一致した見解は得られていない.

本研究の目的は, 体幹肢位掞よび性別が片脚着地時の 膝関節角度と筋活動に及ぼす影響を明らかにし， ACL 損傷の要因検討掞よび予防の一助とすることである。

\section{II. 対象と方法}

\section{1. 対象}

対象はスポーツ活動をしている健常大学生 40 名（男 性 20 名: 年齢 $20.4 \pm 2.6$ 歳, 身長 $170.5 \pm 5.5 \mathrm{~cm}$, 体 重 $63.1 \pm 5.7 \mathrm{~kg}$, 女性 20 名: 年齢 $19.9 \pm 1.2$ 歳, 身長 $160.6 \pm 4.8 \mathrm{~cm}$, 体重 $52.1 \pm 6.7 \mathrm{~kg}$ ) の利き脚 40 脚と した，利き脚はボールを蹴る側と定義し，全例右下肢で あった。除外基準は ACL 損傷の既往がある者, 下肢揖 よび㑒柱の手術歴のある者, 神経学的疾患を有する者, 6 か月以内に下肢・体幹に疼痛や外傷があった者とし た．対象者には事前に研究目的や意義について十分に説 明し，書面にて同意を得た。また本研究は秋田大学大学
A

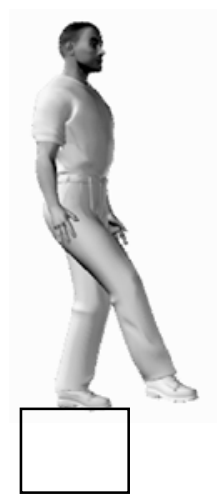

B

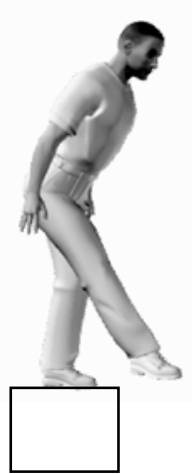

C

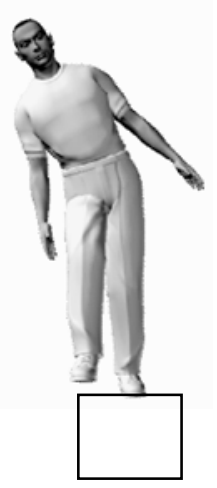

図1片脚着地の開始肢位
(A) 中間肢位,
(B) 体幹屈曲位,
(C) 体幹右側屈位.

院医学系研究科倫理委員会の承認を得て実施した（受付 番号：764).

2. 方法

高さ $40 \mathrm{~cm}$ の台の, 前方に $5 \mathrm{~m}$ 側方に $5 \mathrm{~m}$ 離れた位 置に 1 台ずつデジタルビデオカメラ HDR-HC9 (Sony 社製）を高さ $60 \mathrm{~cm}$ の三脚に設置し，前額面および矢 状面を対象とする動画をサンプリング周波数 $30 \mathrm{~Hz}$ で撮 影した。関節角度の解析のため, 対象者の胸骨柄, 肩峰, 両側上前腸骨棘，大転子，膝蓋骨中央，大腿骨外側上顆， 足関節外果, 内果, 仙骨に 10 個の反射マーカー（丸型, 直径 $25 \mathrm{~mm}$ ）を貼付した。

下肢の表面筋電図は，表面筋電計 ME3000P（Mega 社製）を用いて計測し，被験筋は大腿直筋，大腿二頭筋 とした，表面筋電図を双極誘導するために，銀－塩化銀 電極 2 個を各筋の走行に沿って, 電極間距離 $20 \mathrm{~mm}$ で 貼り付けた，各筋の筋電図導出部位は SENIAM の推奨 する位置 9)を参考に, 大腿直筋では上前腸骨棘と膝蓋 骨上部を結ぶ線の中央, 大腿二頭筋では坐骨結節と脛骨 内側上顆を結ぶ線の中央とし，アース電極の設定部位は 膝蓋骨とした。 また着地した時点を把握するため, 前足 部と後足部にフットスイッチを貼付し，表面筋電図と同 期させた。

対象者に高さ $40 \mathrm{~cm}$ の台からの片脚着地を, 自然で 楽な姿勢 (以下, 中間肢位), 体幹屈曲位, 体幹右側屈 位の 3 条件で行わせた（図 1). 片脚着地の動作は各肢 位とも Blackburn ら 5,10) の方法に基づくものとした。 ま ず測定肢である利き脚を膝関節伸展位にて台上から外し， 反対側下肢の足先を台の前縁に合わせるようにした，次 にその位置より上方へジャンプせずに両下肢とも下方に 降ろし, 測定肢のみで床上に着地するように指示した。 また体幹肢位は台上から着地まで同一肢位を保つよう指 示したが, 体幹屈曲, 右側屈の角度と骨盤傾斜について は対象者の自由とした。

動作課題は，最初に中間肢位での片脚着地を 5 回実施 し, その後体幹屈曲位, または体幹右側屈位での片脚着 地を無作為に各 5 回ずつ行うものとした。各条件間の休 憩は 2 分間とした，その際，仙骨上のマーカーが上方へ $10 \mathrm{~cm}$ 以上変位した場合は, ジャンプと判断しやり直し た。

片脚着地時の体幹および膝関節角度の画像解析には, 二次元動作解析ソフトウェアであるダートフィッシュ・ ソフトウェア（DARTFISH 社製）を使用し，解析はす ベて同一検者が行った。体幹屈曲角度は矢状面の画像よ り肩峰と大転子を結ぶ線と床面からの垂線とのなす角度 とした．体幹側屈角度は前額面の画像より両側上前腸骨 棘を結ぶ線の中点と胸骨柄を結ぶ線と垂直線とのなす角 度とし, 右側屈を正の值, 左側屈を負の值とした。膝関 節屈曲角度は矢状面の画像より大転子 - 大腿骨外側上顆 
一足関節外果を結ぶ線のなす角度，膝関節外反角度は前 額面上の画像より上前腸骨棘 - 膝蓋骨中央 - 足関節内外 果の中央を結ぶ線のなす角度と定義した。、いずれも着地 動作時の最大角度を採用し，5回の平均值を算出した。

表面筋電図については周波数帯域 10〜 $500 \mathrm{~Hz}$, サン プリング周波数 $1,000 \mathrm{~Hz}$ にてパーソナルコンピュータ (NEC 社製) に取り込み, その解析を解析ソフト MegaWin（Mega 社製）を用いて行った。得られた生波 形は, root mean square（時定数 $100 \mathrm{~m}$ 秒）にて平滑化 処理を行い，フットスイッチ信号から接地を特定し，接 地から $100 \mathrm{~m}$ 秒間を解析区間とした。各筋とも5 回の 平均振幅を求め, 最大等尺性収縮時の平均振幅で除して 正規化し, 大腿直筋と大腿二頭筋の比 (hamstrings / quadriceps ratio : HQR）を算出した.

統計学的解析にはSPSS Statistics 19 (IBM 社製) を 使用した。体幹肢位と性別を要因とする二元配置分散分 析を用い, 有意な効果の認められた要因に対しては Tukey 多重比較検定または $\mathrm{t}$ 検定を行った。また体幹の 各角度と, 膝関節角度および HQR との関係を Pearson の相関係数を求めて検討した。 いずれも有意水準は $5 \%$ とした。

\section{III. 結果}

片脚着地時の肢位ごとの各関節角度を男女別に表 1 に 示す，体幹屈曲角度は体幹屈曲位で，体幹右側屈角度は 体幹右側屈位で他の肢位よりも有意に大きかった（それ ぞれ $\mathrm{p}<0.001)$. 膝関節屈曲角度は体幹肢位の影響を受 け $(\mathrm{F}=20.56, \mathrm{p}<0.001)$, 体幹屈曲位では他の肢位に比 べ有意に大きかった $(\mathrm{p}<0.001)$ が，これに対する性別 の影響や交互作用は認められなかった．膝関節外反角度 は体幹肢位（ $\mathrm{F}=46.41, \mathrm{p}<0.001)$, 性別（ $\mathrm{F}=64.81$, $\mathrm{p}<0.001 ）$ の影響を受け，体幹右側屈位では他の肢位よ り，また女性では男性より有意に高值を示した（いずれ も $\mathrm{p}<0.001)$ が，この角度に対する交互作用は認められ なかった。
片脚着地時の肢位ごとの HQR を男女別に表 2 に示す。 HQR は体幹肢位（ $\mathrm{F}=18.88, \mathrm{p}<0.001)$, 性別（ $\mathrm{F}=37.39$, $\mathrm{p}<0.001 ）$ の影響を受け，体幹屈曲位では他の肢位に比 べ, 男性では女性より有意に高かった $(\mathrm{p}<0.001)$ が, これに対する交互作用は認められなかった。

着地時の体幹角度と膝関節角度および HQR との相関 係数を表 3 に示す. 体幹屈曲角度と膝関節屈曲角度およ びHQR との間に, 体幹右側屈角度と膝関節外反角度と の間に中等度の有意な相関が認められた（いずれも $\mathrm{p}<0.001$ ).

\section{IV. 考察}

本研究では体幹屈曲位での着地時の膝関節屈曲角度が, 他の肢位での着地時より有意に大きいことが示された。 Blackburn ら 10) も同様に片脚着地の際, 体幹屈曲位の 方が直立位よりも膝関節屈曲角度が大きかったと報告し ている. また本研究において体幹屈曲角度と膝関節屈曲 角度との間に中等度の相関が認められた（表 3）ことか ら, 片脚着地時に体幹が屈曲するほど膝関節屈曲角度が 増大するものと考えられる。これは体幹屈曲により骨盤 が前傾することで股関節が屈曲位となり，閉運動連鎖に よって着地時に膝関節屈曲が生じやすくなったものと推 測される．膝関節屈曲角度が増大すると膝蓋腱が脛骨長 軸と平行になるため膝前方剪断力が軽減し ACL の緊張 も軽減する 11)ことが報告されている. また膝関節屈曲 によりハムストリングスの付着角度が大きくなり, 前方 剪断力が減少する10) とされており, 膝関節屈曲角度の 増大は ACLの張力を低下させると考えられる。した がって体幹屈曲位での片脚着地は, 他の体幹肢位と比較 して膝関節屈曲角度を増大させ, ACLへ与えるストレ スを軽減するといえる。着地動作における膝関節屈曲角 度の性差については, Lephartら 12) は片脚着地時に女性 の方が男性よりも膝関節屈曲角度が小さいと報告してい るが, 多くの研究では片脚および両脚着地とも初期接地 時の膝関節屈曲角度には差が認められるものの, 最大屈

表 1 着地時の肢位ごとの関節角度（度）

\begin{tabular}{llrllr}
\hline & & \multicolumn{1}{l}{$\begin{array}{l}\text { 体幹 } \\
\text { 屈曲角度 } \mathrm{b}\end{array}$} & $\begin{array}{l}\text { 体幹 } \\
\text { 右側屈角度 } \mathrm{b}\end{array}$ & $\begin{array}{l}\text { 膝関節 } \\
\text { 屈曲角度 } \mathrm{b}\end{array}$ & $\begin{array}{l}\text { 汬関節 } \\
\text { 外反角度 } \mathrm{ab}\end{array}$ \\
\hline 男性 & 中間肢位 & $2.36 \pm 1.34$ & $-1.37 \pm 0.82$ & $53.52 \pm 5.50$ & $5.23 \pm 2.97$ \\
& 体幹屈曲位 & $17.98 \pm 4.65$ & $-1.39 \pm 0.68$ & $60.88 \pm 5.89$ & $4.22 \pm 2.17$ \\
& 体幹右側屈位 & $2.44 \pm 1.97$ & $7.51 \pm 1.31$ & $55.00 \pm 6.26$ & $11.53 \pm 3.05$ \\
女性 & 中間肢位 & $2.06 \pm 1.50$ & $-1.48 \pm 0.79$ & $53.49 \pm 3.90$ & $10.93 \pm 4.37$ \\
& 体幹屈曲位 & $17.58 \pm 2.19$ & $-1.50 \pm 0.83$ & $60.80 \pm 5.35$ & $9.45 \pm 3.92$ \\
& 体幹右側屈位 & $2.14 \pm 1.34$ & $7.62 \pm 0.96$ & $55.65 \pm 4.72$ & $17.80 \pm 5.37$ \\
\hline
\end{tabular}

平均値 \pm 標準偏差. 体幹右側屈角度を正の值, 体幹左側屈角度を負の值で示した。アルファベッ トは性別（a）および体幹肢位（b）が有意（p<0.001）であったことを示す. 
表 2 着地時の肢位別にみた HQR

\begin{tabular}{llr}
\hline & & \multicolumn{1}{c}{$\mathrm{HQR}^{\mathrm{ab}}$} \\
\hline 男性 & 中間肢位 & $0.52 \pm 0.25$ \\
& 体幹屈曲位 & $0.72 \pm 0.22$ \\
& 体幹右側屈位 & $0.40 \pm 0.19$ \\
女性 & 中間肢位 & $20.63 \pm 7.12$ \\
& 体幹屈曲位 & $26.01 \pm 8.10$ \\
& 体幹右側屈位 & $17.57 \pm 5.99$ \\
\hline
\end{tabular}

平均值 \pm 標準偏差. アルファベットは性別（a) および体幹肢位（b）が有意（ $\mathrm{p}<0.001 ）$ であった ことを示す。

曲角度には違いがない13,14) と述べられている。本研究 でも膝関節屈曲角度に性差は見られなかったことから， $\mathrm{ACL}$ 損傷率の男女差に片脚着地時の膝関節屈曲角度の 関与は小さいものと推察される.

これまで片脚着地時の膝関節外反角度を検討した報告 は数多いが 3,4,14-16), 体幹右側屈位で片脚着地させた時 の右膝関節外反角度を検討した報告はない. 体幹右側屈 位で片脚着地させると, 他の着地肢位に比べ膝関節外反 角度は明らかに増大しており，かつ女性の方が男性より 外反角度が大きかった（表 1)。膝関節外反により ACL の張力は増加 ${ }^{17)}$ し, 内外反中間位より外反角度が 5 度 増加すると ACLへの負荷は6倍になる18)とされている. また着地動作やサイドステップの際に膝関節が外反位で あると, 大きな外反モーメントを引き起こす 14,19) とさ れ, さらに Fleming ら 20) は非荷重下での膝関節外反モー メントは ACL の張力に影響しないのに対し, 荷重下で は ACL の緊張を増加させると報告している。これらは 片脚着地時の膝関節外反角度増加が, ACL 損傷のリス クファクターであることの裏付けになると考えられる. よって右側屈位での右下肢片脚着地は, 右膝関節の ACLへのストレスを増加させ ACL 損傷につながる危険 な肢位であるといえる。着地動作では, 女性は男性に比 べ膝関節外反角度が大きい14,16) とされており, 非接触 性の ACL 損傷時の映像解析においても女性の方が男性 よりも膝関節外反角度が大きい21)ことが示されている. 男性に比べ女性では片脚着地時の膝関節外反角度が大き い点が ACL 損傷が女性に多いことの一因と考えられる。

ACLの張力は大腿四頭筋の筋活動増加に従って増 大 22)するとされている. 一方，八ムストリングスの筋 活動は ACL の張力を軽減 23)させ，大腿四頭筋との同 時収縮の際も, 大腿四頭筋の単独収縮に比べて脛骨の前 方移動を減少 24)させると報告されている。高杉ら 25) は バスケットボール選手における下肢筋力の男女差を調査 し，女性は男性に比べ大腿四頭筋の遠心性筋力優位性が あり，特に跳躍頻度の高い選手で顕著であったと報告し ている，本研究では，女性では体幹の肢位にかかわらず
表 3 着地時の体幹角度と膝関節角度および HQR との 相関係数

\begin{tabular}{lll}
\hline & 体幹屈曲角度 & 体幹右側屈角度 \\
\hline 膝関節屈曲角度 & $\mathrm{r}=0.517 * *$ & $\mathrm{r}=-0.115$ \\
膝関節外反角度 & $\mathrm{r}=-0.359$ & $\mathrm{r}=-0.559^{* *}$ \\
$\mathrm{HQR}$ & $\mathrm{r}=0.483 * *$ & $\mathrm{r}=0.295$ \\
\hline
\end{tabular}

Pearson の相関係数. $* * \mathrm{p}<0.001$.

片脚着地時の HQR が男性に比べ有意に低く，この性差 が男性に比して女性で ACL 損傷が多いことの一因と考 えられる。

以上より, ACL 損傷の発生には体幹肢位および性別 のどちらの要因も関与していることが示された。 した がって理学療法において片脚着地動作を指導する際には, 体幹側屈位を避け体幹屈曲位で行うことが重要であると 考えられる。また膝関節外反や HQR の低下など女性に 特異的な因子を考慮してトレーニングを実施していくこ とも予防上重要であるといえる.

なお本研究の限界は, 膝関節外反角度の解析に二次元 動作解析ソフトウェアを用いたことである。この方法で は膝関節屈曲時に股関節回旋によるみかけの膝関節外反 が起こりやすい 15) と指摘されている. しかし McLean ら26) はサイドステップとサイドジャンプにおいて, 2 次元で解析した膝関節外反角度と 3 次元で解析した角度 との間に高い相関を認めたと報告している。しがって本 研究の解析においても膝関節外反角度を反映していたも のと推察されるが, 今後は股関節の影響を補正した解析 方法など更なる検討が必要であると考える.

\section{引用文献}

1) Boden BP, Dean GS, Feagin JA, et al.: Mechanisms of anterior cruciate ligament injury. Orthopedics, 2000, 23(6): 573-578.

2) Ferretti A, Papandrea P, Conteduca F, et al.: Knee ligament injuries in volleyball players. Am J Sports Med, 1992, 20(2): 203-207.

3) Ford KR, Myer GD, Hewett TE: Valgus knee motion during landing in high school female and male basketball players. Med Sci Sports Exerc, 2003, 35(10): 1745-1750.

4) Hewett TE, Myer GD, Ford KR, et al.: Biomechanical measures of neuromuscular control and valgus loading of the knee predict anterior cruciate ligament injury risk in female athletes: a prospective study. Am J Sports Med, 2005, 33(4): 492-501.

5) Blackburn JT, Padua DA: Sagittal-plane trunk position, landing forces, and quadriceps electromyographic activity. $\mathrm{J}$ Athl Train, 2009, 44(2): 174-179.

6) Hewett TE, Torg JS, Boden BP: Video analysis of trunk and knee motion during non-contact anterior cruciate ligament injury in female athletes: lateral trunk and knee abduction motion are combined components of the injury mechanism. $\mathrm{Br}$ 
J Sports Med, 2009, 43(6): 417-422.

7) Arendt E, Dick R: Knee injury patterns among men and women in collegiate basketball and soccer. NCAA data and review of literature. Am J Sports Med, 1995, 23(6): 694-701.

8) Ireland ML: Anterior cruciate ligament injury in female athletes: epidemiology. J Athl Train, 1999, 34(2): 150-154.

9) 下野俊哉：表面筋電図マニュアル基礎編。酒井医療, 東京, 2004, p107, 110.

10) Blackburn JT, Padua DA: Influence of trunk flexion on hip and knee joint kinematics during a controlled drop landing. Clin Biomech (Bristol, Avon), 2008, 23(3): 313-319.

11) Kernozek TW, Ragan RJ: Estimation of anterior cruciate ligament tension from inverse dynamics data and electromyography in females during drop landing. Clin Biomech (Bristol, Avon), 2008, 23(10): 1279-1286.

12) Lephart SM, Ferris CM, Riemann BL, et al.: Gender differences in strength and lower extremity kinematics during landing. Clin Orthop Relat Res, 2002, (401): 162-169.

13) Huston LJ, Vibert B, Ashton-Miller JA, et al.: Gender differences in knee angle when landing from a drop-jump. Am J Knee Surg, 2001, 14(4): 215-219.

14) Kernozek TW, Torry MR, VAN Hoof H, et al.: Gender differences in frontal and sagittal plane biomechanics during drop landings. Med Sci Sports Exerc, 2005, 37(6): 1003-1012.

15) Noyes FR, Barber-Westin SD, Fleckenstein C, et al.: The drop-jump screening test: difference in lower limb control by gender and effect of neuromuscular training in female athletes. Am J Sports Med, 2005, 33(2): 197-207.

16) Russell KA, Palmieri RM, Zinder SM, et al.: Sex differences in valgus knee angle during a single-leg drop jump. J Athl Train, 2006, 41(2): 166-171.

17) Fukuda Y, Woo SL, Loh JC, et al.: A quantitative analysis of valgus torque on the ACL: a human cadaveric study. J Orthop Res, 2003, 21(6): 1107-1112.

18) Bendjaballah MZ, Shirazi-Adl A, Zukor DJ: Finite element analysis of human knee joint in varus-valgus. Clin Biomech (Bristol, Avon), 1997, 12(3): 139-148.

19) McLean SG, Walker KB, van den Bogert AJ: Effect of gender on lower extremity kinematics during rapid direction changes: an integrated analysis of three sports movements. J Sci Med Sport, 2005, 8(4): 411-422.

20) Fleming BC, Renstrom PA, Beynnon BD, et al.: The effect of weightbearing and external loading on anterior cruciate ligament strain. J Biomech, 2001, 34(2): 163-170.

21) Krosshaug T, Nakamae A, Boden BP, et al.: Mechanisms of anterior cruciate ligament injury in basketball: video analysis of 39 cases. Am J Sports Med, 2007, 35(3): 359-367.

22) Pandy MG, Shelburne KB: Dependence of cruciate-ligament loading on muscle forces and external load. J Biomech, 1997, 30(10): 1015-1024.

23) Beynnon BD, Fleming BC: Anterior cruciate ligament strain in-vivo: a review of previous work. J Biomech, 1998, 31(6): 519-525.

24) Li G, Rudy TW, Sakane M, et al.: The importance of quadriceps and hamstring muscle loading on knee kinematics and in-situ forces in the ACL. J Biomech, 1999, 32(4): 395-400.

25) 高杉紳一郎, 上島隆秀, 林 和生・他：高校バスケットボー ル一流選手の膝屈伸筋力特性と競技能力 ACL 損傷発生機序 の考察。整形外科と災害外科, 1995，44(2): 616-620.

26) McLean SG, Walker K, Ford KR, et al.: Evaluation of a two dimensional analysis method as a screening and evaluation tool for anterior cruciate ligament injury. Br J Sports Med, 2005, 39(6): 355-362. 